\title{
FAKTOR-FAKTOR YANG BERHUBUNGAN DENGAN KEJADIAN BERAT BADAN LAHIR RENDAH (BBLR)
}

\author{
Fitri Nur Indah ${ }^{1}$, Istri Utami ${ }^{2}$ \\ ${ }^{1,2}$ Fakultas Ilmu Kesehatan Universitas 'Aisyiyah Yogyakarta \\ Ifitrinurindah1998@gmail.com; ${ }^{2}$ istriutami@unisayogya.ac.id
}

\begin{abstract}
Abstrak
Latar Belakang: Berat badan lahir rendah (BBLR) merupakan suatu keadaan dimana bayi baru lahir yang memiliki berat badan kurang dari 2.500 gram. Bayi BBLR memiliki peluang kematian delapan kali lebih besar dibandingkan dengan bayi tidak BBLR.

Tujuan: Penelitian ini bertujuan untuk mengetahui faktor-faktor yang berhubungan dengan kejadian BBLR di RSUD Panembahan Senopati Bantul, Yogyakarta. Metode: Analisis observasional analitik dengan pendekatan case control dan retrospektif. Teknik pengambilan sampel didalam penelitian ini menggunakan Simple Random Sampling. Populasi didalam penelitian ini yaitu seluruh bayi yang lahir di RSUD Panembahan Senopati Bantul Tahun 2017 dan jumlah sampel 406 bayi (203 kasus, 203 kontrol). Alat yang digunakan dalam pengambilan data yaitu menggunakan master table. Analisis menggunakan Chi Square.

Hasil: Data penelitian ini didapatkan hasil bahwa usia ibu memiliki $p$ value $=0,07$, paritas memiliki $p$ value $=0,03$, jarak kelahiran memiliki nilai $p$ value $=0,01, \mathrm{OR}=1,77$, usia kehamilan memiliki nilai $p$ value $=0,00, \mathrm{OR}=21,76$, anemia memiliki nilai $p$ value $=1,00$, preeklampsia memiliki nilai $p$ value $=0,00, \mathrm{OR}=23,74$, dan gemelli memiliki nilai $p$ value $=0,00 . \mathrm{OR}=10,46$.

Simpulan dan Saran: Faktor-faktor yang mempengaruhi kejadian BBLR di RSUD Panembahan Senopati Bantul adalah paritas, jarak kelahiran, usia kehamilan, preeklampsia dan gemelli. Bagi tenaga kesehatan khususnya bidan, agar lebih meningkatkan kerjasama dengan kader posyandu disetiap wilayah untuk pemantauan pemenuhan gizi ibu selama hamil. Sehingga ibu yang diduga beresiko melahirkan BBLR dapat dideteksi secara dini.
\end{abstract}

Kata Kunci: Gemelli, Jarak Kelahiran, Paritas, Preeklampsia, Usia Kehamilan.

\begin{abstract}
Background: Low birth weight $(L B W)$ is a condition in which a newborn baby weigh less than 2,500 grams. $L B W$ babies have eight times the chance of death compared to babies who are not $L B W$. The results of the preliminary study at Panembahan Senopati Bantul Hospital in 2017 had an average prevalence of LBW rates of 13.34\%, and the mortality rate caused by $L B W$ was $79.54 \%$.

Objective: This study aimed to determine the factors associated with the incidence of $L B W$ in Panembahan Senopati Bantul Yogyakarta Hospital.

Methods: Analytical observational analysis with a case control and retrospective approach was applied in the study. The sampling technique in this study used Simple Random Sampling. The population in this study were all babies born in Panembahan Senopati Bantul Hospital in 2017 and a total sample of 406 infants (203 cases, 203 controls). The tool used in this study is the master table. Analysis applied Chi Square.

Results: The data of this study showed that maternal age had $p$ value $=0.07$, parity had $p$ value $=0.03$, birth distance had a $p$ value $=0.01, O R=1.77$, gestational age had a $p$ value $=0.00, O R=21.76$, anemia has a value of $p$ value $=1.00$, preeclampsia has a value
\end{abstract}


of $p$ value $=0.00, O R=23.74$, and gamely obtained a value of $p$ value $=0.00$. OR $=10.46$. Conclusion and Suggestion: The factors that influenced the incidence of $L B W$ in Panembahan Senopati Bantul Hospital were parity, birth distance, gestational age, preeclampsia and gamelli. It is expected that health workers especially midwives enhance collaboration with community health unit's cadres in each region for monitoring maternal nutrition during pregnancy. Hence, mothers suspected of having a risk of having $L B W$ can be detected early.

Keywords: Birth Distance, Gamelli, Gestasional Age LBW, Parity, Preeclampsia.

\section{Pendahuluan}

Upaya pemeliharaan kesehatan anak dilakukan sejak janin masih dalam kandungan, dilahirkan, setelah dilahirkan, dan sampai berusia 18 tahun. Indikator angka kematian yang berhubungan dengan anak yakni Angka Kematian Neonatal $(\mathrm{AKN})$, Angka Kematian Bayi (AKB), dan Angka Kematian Balita (AKABA). Hasil Survei Demografi dan Kesehatan Indonesia (SDKI) pada tahun 2017 menunjukkan AKN sebesar 15 per 1.000 kelahiran hidup, AKB 24 per 1.000 kelahiran hidup, dan AKABA 32 per 1.000 kelahiran hidup (Kemenkes, 2017). Neonatus adalah bayi baru lahir sampai dengan usia 28 hari. Pada masa tersebut terjadi perubahan yang sangat besar dari kehidupan di dalam rahim dan terjadi pematangan organ hampir pada semua sistem. Bayi hingga usia kurang dari satu bulan merupakan golongan umur yang memiliki resiko gangguan kesehatan paling tinggi dan berbagai masalah kesehatan bisa muncul. Sehingga tanpa penanganan yang tepat, bisa berakibat fatal terutama penanganan pada bayi dengan riwayat berat badan lahir rendah (Kemenkes, 2017).

Masalah yang sering terjadi pada bayi BBLR adalah hipotermi, hipoglikemi, dan masalah pemberian ASI karena bayi dengan BBLR hanya memiliki sedikit lemak dalam tubuh dan sistem pengaturan suhu tubuh belum matang serta reflek hisap dan telan bayi masih lemah. Pada bayi BBLR banyak sekali resiko terjadi permasalahan pada sistem tubuh, oleh karena kondisi tubuh yang tidak stabil. Peluang kematian perinatal pada bayi BBLR adalah delapan kali lebih besar dari bayi normal. Kejadian berat badan lahir rendah dipengaruhi oleh beberapa faktor yaitu faktor ibu, faktor janin dan faktor lingkungan (Proverawati \& Ismawati, 2010).

Berdasarkan Survei Demografi Kesehatan Indonesia (SDKI) (2017) angka kejadian Berat Badan Lahir Rendah (BBLR) di Indonesia mencapai prosentase 
6,2 \%. Provinsi Sulawesi Tengah menduduki peringkat pertama kejadian BBLR yaitu 8,9\%, sedangkan provinsi yang memiliki prosentasi angka kejadian BBLR paling rendah adalah Provinsi Jambi dengan prosentase 2,6 \% (RISKESDAS, 2018). Profil Kesehatan DIY (2017), angka kejadian BBLR di DIY mengalami fluktuatif dari tahun 2014 hingga tahun 2017 yaitu pada tahun 2014 (4,71\%), tahun 2015 (5,32\%), tahun 2016 (5,20\%), dan pada tahun 2017 (4,86\%). Dari 5 Kabupaten di DIY prevalensi BBLR di Kabupaten Kulon Progo mengalami posisi pertama yaitu 6,69\%, Kabupaten Gunung Kidul 5,67\%, Kabupaten Yogyakarta 5,16\%, Kabupaten Sleman 4,65\%, dan Kabupaten Bantul 3,79\%. Walaupun prosentase kejadian BBLR di Kabupaten Bantul paling rendah, namun dalam kurun waktu tahun 2014 hingga 2017 angka kejadian BBLR di Kabupaten Bantul selalu mengalami kenaikkan, yaitu pada tahun 2014 (3,58\%), tahun 2015 (3,62\%), tahun $2016(3,66 \%)$ dan pada tahun 2017 mencapai prosentase (3,79\%) (Profil Kesehatan DIY, 2017). Hasil studi pendahuluan yang telah dilakukan peneliti di RSUD Panembahan Senopati Bantul didapatkan data bayi dengan BBLR pada tahun 2017 sebanyak 361 dari 2.706 kelahiran. Berdasarkan uraian datas peneliti merasa tertarik untuk meneliti tentang faktor-faktor yang berhubungan dengan kejadian bayi berat lahir rendah (BBLR) di RSUD Panembahan Senopati Bantul tahun 2017. Tujuan penelitian ini untuk mengetahui faktor-faktor yang berhubungan dengan kejadian BBLR di RSUD Panembahan Senopati Bantul, Yogyakarta.

\section{Metode Penelitian}

Penelitian ini merupakan penelitian observasional analitik dengan pendekatan waktu case control dan retrospektif. Jenis data yang digunakan yaitu data sekunder dimana data diperoleh dari rekam medis pasien dengan BBLR di RSUD Panembahan Senopati Bantul pada tahun 2017. Alat yang digunakan untuk pengumpulan data yaitu menggunakan master table. Peneliti mengumpulkan data dengan cara mengumpulkan informasi dari rekam medis pasien berupa berat badan bayi, usia ibu, paritas, jarak kehamilan, usia kehamilan, anemia, preeklampsia, dan kehamilan ganda. Pengambilan sampel dalam penelitian ini menggunakan teknik probability sampling yaitu simple random sampling. Analisis data yaitu univariat persentase dan bivariate analisis Chi Square. Populasi didalam penelitian ini yaitu seluruh bayi yang lahir di RSUD Panembahan Senopati Bantul Tahun 2017 dan 
jumlah sampel 406 bayi (203 kasus, 203 kontrol). Pada penelitian ini menjunjung tinggi prinsip etika penelitian dimana peneliti memperkecil dan memaksimalkan manfaat, menghormati martabat manusia dan menjaga privasi manusia.

\section{Hasil Analisis}

\section{Analisis Univariat}

a. Distribusi frekuensi BBLR di RSUD Panembahan Senopati Bantul Yogyakarta Tahun 2017

\begin{tabular}{lcc}
\hline \multicolumn{1}{c}{ BAYI } & Frekuensi & \% \\
\hline BBLR (Bayi berat badan lahir rendah) & 174 & 100 \\
Total & 174 & 100 \\
\hline
\end{tabular}

Dapat dilihat bahwa bayi yang lahir BBLRberjumlah 174 bayi.

b. Distribusi frekuensi usia ibu di RSUD Panembahan Senopati Bantul

\begin{tabular}{lcc}
\hline \multicolumn{1}{c}{ Usia Ibu } & Frekuensi & $\%$ \\
\hline Usia $<20$ tahun & 12 & 6,9 \\
Usia 20-35 tahun & 140 & 80,5 \\
Usia $>35$ tahun & 22 & 12,6 \\
Total & 174 & 100 \\
\hline \multicolumn{2}{c}{ Dapat dilihat karakteristik untuk usia ibu paling banyak pada usia }
\end{tabular}

20-35 tahun sebanyak 140 orang $(80,5 \%)$.

c. Distribusi frekuensi paritas di RSUD Panembahan Senopati Bantul

\begin{tabular}{lcc}
\hline \multicolumn{1}{c}{ Paritas } & Frekuensi & \% \\
\hline Primipara (kehamilan pertama) & 84 & 48,3 \\
Multipara (kehamilan 2-4) & 84 & 48,3 \\
Grandemultipara (kehamilan >4) & 6 & 3,4 \\
Total & 174 & 100 \\
\hline \multicolumn{2}{c}{ Paritas yang menjadi mayoritas di RSUD Panembahan Senopati }
\end{tabular}

Bantul adalah multipara dan primipara dengan jumlah yang sama yaitu sebanyak 84 orang $(48,3 \%)$.

d. Distribusi frekuensi jarak kelahiran di RSUD Panembahan Senopati Bantul

\begin{tabular}{lcc}
\hline \multicolumn{1}{c}{ Jarak Kehamilan } & Frekuensi & \% \\
\hline Beresiko $(<2$ tahun) & 84 & 48,3 \\
Tidak Beresiko $(>2$ tahun) & 90 & 51,7 \\
Total & 174 & 100 \\
\hline \multicolumn{2}{c}{ Pada ibu yang melahirkan mayoritas } & memiliki jarak kelahirannya
\end{tabular}

beresiko yaitu sebanyak 90 orang $(51,7 \%)$.

e. Distribusi frekuensi usia kehamilan di RSUD Panembahan Senopati Bantul

\begin{tabular}{lcc}
\hline \multicolumn{1}{c}{ Usia Kehamilan } & Frekuensi & \% \\
\hline Preterm (<37 minggu) & 83 & 47,7 \\
Aterm (37-42 minggu) & 91 & 52,3
\end{tabular}


Total

174

100

Mayoritas ibu yang melahirkan di RSUD Panembahan Senopati

Bantul adalah usia kehamilan aterm yaitu sebanyak 91 orang (52,3\%).

f. Distribusi frekuensi anemia di RSUD Panembahan Senopati Bantul

\begin{tabular}{lcc}
\hline \multicolumn{1}{c}{ Anemia } & Frekuensi & \% \\
\hline Anemia $(\mathrm{Hb}<11 \mathrm{gr} / \mathrm{dl})$ & 5 & 2,9 \\
Tidak Anemia $(\mathrm{Hb} \geq 11 \mathrm{gr} / \mathrm{dl})$ & 169 & 97,1 \\
Total & 174 & 100 \\
\hline
\end{tabular}

Ibu yang melahirkan di RSUD Panembahan Senopati Bantul pada

tahun 2017 mayoritas tidak mengalami anemia sebanyak 169 orang $(97,1 \%)$.

g. Distribusi frekuensi preeklampsia di RSUD Panembahan Senopati Bantul

\begin{tabular}{lcc}
\hline \multicolumn{1}{c}{ Preeklampsia } & Frekuensi & \% \\
\hline Preeklampsia (terdapat protein didalam urine) & 21 & 12,1 \\
Tidak Preeklampsia (tidak terdapat protein didalam & 153 & 87,9 \\
urine) & & 100 \\
Total & Mayoritas ibu yang melahirkan di RSUD & Panembahan Senopati
\end{tabular}

Bantul tidak mengalami Preeklampsia yaitu sebanyak 153 orang (87,9\%).

h. Distribusi frekuensi gemelli di RSUD Panembahan Senopati Bantul

\begin{tabular}{llcc}
\hline & Gemelli & Frekuensi & \% \\
\hline Gemelli & & 27 & 15,5 \\
Tidak Gemelli & & 147 & 84,5 \\
Total & 174 & 100 \\
\hline
\end{tabular}

Mayoritas ibu yang melahirkan di RSUD Panembahan Senopati

Bantul adalah kehamilan tunggal sebanyak 147 (84,5\%).

\section{Analisis Bivariat}

a. Distribusi frekuensi berdasarkan usia ibu di RSUD Panembahan Senopati Bantul Yogyakarta Tahun 2017

\begin{tabular}{lccc}
\hline \multicolumn{1}{c}{ Usia Ibu } & \multicolumn{2}{c}{ BBLR } & \multirow{2}{*}{ Nilai p } \\
\cline { 2 - 3 } & F & \% & \\
\hline Usia $<$ 20 tahun & 12 & 6,9 & \\
Usia 20-35 tahun & 140 & 80,5 & 0,070 \\
Usia $>$ 35 tahun & 22 & 12,6 & \\
Total & 174 & 100 & \\
\hline
\end{tabular}

Berdasarkan tabel dapat diketahui BBLR di RSUD Panembahan

Senopati Bantul yang paling tinggi berasal dari ibu usia 20-35 tahun sebanyak 140 orang $(80,5 \%)$ dan yang paling rendah pada usia $<20$ tahun sebanyak 12 orang (6,9\%). Diperoleh nilai $\mathrm{p}=0,070$ maka dapat disimpulkan bahwa tidak ada hubungan yang bermakna antara usia ibu dengan BBLR karena nilai p $(0,070>0,05)$. 
Reproduksi sehat untuk hamil dan melahirkan adalah usia 20 -35 tahun, jika terjadi kehamilan dibawah atau diatas usia tersebut maka akan dikatakan beresiko terjadinya kematian 2-4 kali lebih tinggi dari reproduksi sehat. Penyulit kehamilan remaja $(<20$ tahun $)$ lebih tinggi dibandingkan kurun waktu reproduksi sehat antara 20 - 35 tahun. Keadaan tersebut akan semakin menyulitkan ditambah dengan tekanan (stress), psikologi, sosial, ekonomi sehingga memudahkan terjadinya keguguran, anemia, gangguan tumbuh kembang janin, keguguran, prematuritas, BBLR, gangguan persalinan, preeklampsia, perdarahan antapartum (Manuaba, 2010).

Pada penelitian ini didapatkan bahwa ibu yang melahirkan BBLR lebih banyak pada usia 20 - 35 tahun sebanyak 140 orang $(80,5 \%)$ dibandingkan dengan usia yang tidak aman dalam kehamilan. Hal ini tidak sesuai dengan teori (Holmes \& Baker, 2011) yaitu usia kehamilan yang baik adalah 20-35 tahun. Hasil penelitian ini di dukung oleh penelitian Ernawati (2016) dengan hasil tidak ada hubungan yang bermakna antara usia ibu dengan kejadian BBLR dengan $p$ value 0,35 karena usia bukan satu-satunya yang menyebabkan BBLR, usia juga tidak selalu mempunyai pengaruh negatif terhadap kesehatan seseorang. Pada penelitian ini responden yang memiliki usia tidak beresiko melahirkan BBLR sebesar 80,5\%, hal ini dipengaruhi oleh faktor pekerjaan dan pendidikan ibu yang masih rendah. Ibu hamil dengan tingkat pendidikan rendah memiliki resiko 19,190 kali lebih besar untuk melahirkan BBLR dibandingkan ibu hamil dengan tingkat pendidikan tinggi.

Penelitian ini tidak sejalan dengan penelitian Pinontoan (2015) di RSUP Prof. Dr.R.D. Kandou di Manado dengan hasil terdapat hubungan yang signifikan antara usia ibu dengan kejadian BBLR. Usia ibu saat kehamilan erat kaitannya dengan berat badan bayi. Selain faktor usia ibu, didukung juga dengan faktor-faktor lain agar bayi menjadi sehat salah satunya adalah faktor ekonomi yang dapat berpengaruh pada konsumsi nutrisi ibu selama hamil dan berpengaruh terhadap kesejahteraan janin. 
b. Distribusi frekuensi berdasarkan paritas di RSUD Panembahan Senopati Bantul Yogyakarta Tahun 2017

\begin{tabular}{|c|c|c|c|}
\hline \multirow[t]{2}{*}{ Paritas } & \multicolumn{2}{|c|}{ BBLR } & \multirow[t]{2}{*}{ Nilai $p$} \\
\hline & $\mathbf{F}$ & $\%$ & \\
\hline Primipara (kehamilan pertama) & 84 & 48,3 & \\
\hline Multipara (kehamilan 2-4) & 84 & 48,3 & 0,033 \\
\hline Grandemultipara (kehamilan > 4) & 6 & 3,4 & \\
\hline Total & 174 & 100 & \\
\hline
\end{tabular}
memiliki paritas primipara dan multipara dengan hasil yang sama yaitu 84 orang $(48,3 \%)$, dan yang paling rendah adalah ibu yang mempunyai paritas grandemultipara sebanyak 6 orang $(3,4 \%)$. Diperoleh nilai $\mathrm{p}=0,033$ maka dapat disimpulkan bahwa terdapat hubungan yang bermakna antara paritas dengan BBLR karena nilai $\mathrm{p}(0,033<0,05)$.

Hasil penelitian ini menunjukkan bahwa paritas seorang ibu memiliki hubungan yang bermakna dengan kejadian BBLR hasil yang didapatkan bahwa ibu primipara atau multipara sama - sama melahirkan bayi BBLR dengan hasil 48,3\%. Dari hasil yang diperoleh perbandingan antara primipara dan multipara memiliki jumlah frekuensi yang sama. Ibu dengan paritas 1 dan $\geq 4$ beresiko melahirkan BBLR, pada primipara terkait belum memiliki pengalaman sebelumnya dalam kehamilan dan persalinan sehingga bisa terjadi karena status gizi yang tidak adekuat dimana hal tersebut mempengaruhi berat bayi yang dilahirkan, kunjungan ANC yang kurang serta pengetahuan perawatan selama kehamilan yang belum memadai dan kondisi psikologis terutama kesiapan dalam menerima kehamilan. Penelitian ini sejalan dengan penelitian Ernawati (2016) yang mengatakan bahwa adanya hubungan yang signifikan antara paritas dengan kejadian BBLR, hal tersebut dipengaruhi oleh faktor usia ibu >35 tahun. Pada usia diatas 35 tahun telah terjadi kemunduran fungsi fisiologis maupun reproduksi secara umum yang mengakibatkan proses perkembangan janin menjadi tidak optimal dan menghasilkan bayi dengan berat badan lahir rendah. Hal ini karena setiap kehamilan yang disusul dengan persalinan akan menyebabkan kelainan uterus. Selain itu, kehamilan yang berulangulang juga akan mempengaruhi sirkulasi nutrisi ke janin, keadaan ini 
menyebabkan gangguan pertumbuhan janin sehingga bayi lahir dengan berat badan lahir rendah.

Hasil penelitian ini sejalan dengan penelitian Pamungkas (2016) bahwa terdapat hubungan yang signifikan antara paritas primipara dengan kejadian BBLR dengan nilai $p$ value 0,000. Dari hasil penelitian tersebut dari 20 responden terdapat 14 orang primipara (56\%) yang melahirkan BBLR.

c. Distribusi frekuensi berdasarkan jarak kelahiran di RSUD Panembahan Senopati Bantul Yogyakarta Tahun 2017

\begin{tabular}{lccc}
\hline \multicolumn{1}{c}{ Jarak Kelahiran } & \multicolumn{2}{c}{ BBLR } & \multirow{2}{*}{ Nilai p } \\
\cline { 2 - 3 } & F & \% & \\
\hline Beresiko $(<2$ tahun) & 84 & 48,3 & \\
Tidak Beresiko $(>2$ tahun) & 90 & 51,7 & 0,012 \\
Total & 174 & 100 & \\
\hline
\end{tabular}

Berdasarkan tabel ibu yang melahirkan BBLR lebih tinggi pada ibu dengan jarak kelahiran $>2$ tahun sebanyak 90 orang $(51,7 \%)$ dan yang $\leq 2$ tahun lebih rendah yaitu 84 orang $(48,3$ Diperoleh nilai $\mathrm{p}=0,012$ maka dapat disimpulkan bahwa terdapat hubungan yang bermakna antara jarak kelahiran dengan BBLR karena nilai $\mathrm{p}(0,012<0,05)$. Dari nilai OR dapat dilihat bahwa odds ratio pada ibu yang memiliki jarak kelahiran $\leq 2$ tahun beresiko melahirkan BBLR 1,77 kali lebih besar dibandingkan dengan ibu yang memiliki jarak kelahiran $>2$ tahun.

Jarak kelahiran adalah jarak antara waktu sejak ibu hamil sampai terjadinya kelahiran berikutnya. Jarak yang terlalu dekat dapat menyebabkan anemia. Hal ini karena kondisi ibu yang masih belum kembali dan zat gizi yang belum optimal, dan harus sudah memenuhi kebutuhan nutrisi janin yang dikandungnya (Kemenkes RI, 2013).

Didalam penelitian ini mayoritas ibu yang melahirkan BBLR adalah ibu yang mempunyai jarak kelahiran $>2$ tahun sebanyak 51,7\%. Ibu yang melahirkan bayi BBLR tetapi mempunyai jarak kelahiran $>2$ tahun bisa disebabkan oleh usia ibu > 35 tahun yang pada usia itu ibu sudah dalam cakupan resiko untuk hamil. Kehamilan yang sehat bukan hanya berasal dari hasil kehamilan itu sendiri. Kurangnya asupan gizi pada ibu bisa disebabkan dari beberapa faktor salah satunya adalah kemampuan ekonomi dari 
keluarga tersebut dalam pemenuhan nutrisi selama kehamilan. Berdasarkan data dari profil kesehatan Kabupaten Bantul (2018) angka kemiskinan di Bantul sebesar 54,09\% sehingga angka tersebut mencerminkan pemenuhan kebutuhan nutrisi bagi ibu hamil didalam suatu keluarga.

Hal ini sesuai dengan penelitian Sharesta (2016) mengatakan bahwa ibu yang hamil dengan jarak kelahiran $>2$ tahun atau $<2$ tahun sama-sama menghasilkan bayi BBLR dengan hasil 30,3\% dan 31,1\% sehingga dikatakan pada penelitian ini tidak ada hubungan antara paritas dengan BBLR. Penelitian Setiati (2017) sejalan dengan penelitian ini yaitu mayoritas ibu yang melahirkan BBLR adalah ibu yang mempunyai jarak kelahiran > 2 tahun sebanyak 82,3\%.

d. Distribusi frekuensi berdasarkan usia kehamilan di RSUD Panembahan Senopati Bantul Yogyakarta Tahun 2017

\begin{tabular}{|c|c|c|c|}
\hline \multirow[t]{2}{*}{ Usia Kehamilan } & \multicolumn{2}{|c|}{ BBLR } & \multirow[t]{2}{*}{ Nilai $p$} \\
\hline & $\mathbf{F}$ & $\%$ & \\
\hline Preterm $(<37$ minggu $)$ & 83 & 47,7 & \\
\hline Aterm (37-42 minggu) & 91 & 52,3 & 0,000 \\
\hline Total & 174 & 100 & \\
\hline
\end{tabular}
ibu dengan usia kehamilan aterm yaitu sebanyak 91 orang $(52,3 \%)$ dan ibu dengan usia kehamilan preterm lebih rendah yaitu 83 orang $(47,7 \%)$. Diperoleh nilai $\mathrm{p}=0,000$ maka dapat disimpulkan bahwa terdapat hubungan yang bermakna antara usia kehamilan dengan BBLR karena nilai p $(0,000<$ 0,05). Dari nilai OR dapat dilihat bahwa odds ratio pada usia kehamilan yang preterm (<37 minggu) beresiko melahirkan BBLR 21,76 kali lebih besar dibandingkan dengan usia kehamilan yang aterm.

Usia kehamilan menurut KBBI adalah ukuran lama waktu seorang janin berada dalam rahim. Berat badan bayi semakin bertambah sesuai dengan usia kehamilan. Faktor usia kehamilan mempengaruhi kejadian BBLR karena semakin pendek masa kehamilan semakin kurang sempurna pertumbuhan alat-alat tubuhnya sehingga akan turut mempengaruhi berat badan bayi sehingga dapat dikatakan bahwa usia kehamilan mempengaruhi kejadian BBLR (Manuaba, 2010). Organ vital janin akan terbentuk pada kehamilan trimester I, pada trimester berikutnya hanya bersifat 
menyempurnakan saja, artinya jika organ vital pada trimester I terbentuk tidak sempurna atau mengalami kekurangan nutrisi makanan akan melahirkan bayi yang tidak sempurna, premature, dan BBLR (Proverawati \& Ismawati, 2010).

Pada hasil penelitian ini didapatkan hasil bahwa ibu yang melahirkan BBLR lebih banyak pada usia kehamilan aterm sebanyak 91 orang (52,3\%) sehingga tidak sesuai dengan teori yang ada bahwa resiko BBLR didapatkan dari ibu yang melahirkan preterm karena semakin bertambahnya usia kehamilan seharusnya berat badan bayi semakin bertambah (Proverawati \& Ismawati, 2010). Penelitian ini sejalan dengan penelitian Handayani (2017) dengan hasil bahwa ibu yang melahirkan BBLR lebih banyak pada usia kehamilan aterm. Salah satu faktor penyebab terjadinya pembentukan bayi secara tidak sempurna adalah pemenuhan nutrisi dan usia ibu pada saat mengandung. Data profil kesehatan Kabupaten Bantul (2018) menunjukkan bahwa kunjungan K4 pada tahun 2017 sudah mencapai 92,03\% artinya ibu yang melakukan pemeriksaan K4 sudah dalam usia aterm. Hal tersebut menunjukkan adanya kesenjangan antara pemeriksaan K4 dengan ibu yang melahirkan BBLR, seharusnya bisa mendeteksi adanya kelainan pada ibu hamil saat melakukan pemeriksaan ANC (antenatal care). Sehingga ini yang masih menjadi salah satu penyebab hasil penelitian ini mendapatkan ibu yang melahirkan BBLR dalam usia kehamilan aterm. Hasil penelitian ini didukung oleh penelitian Khotimah (2017) yang mengatakan bahwa usia kehamilan memiliki hubungan yang signifikan dengan kejadian BBLR dengan nilai $p$ value 0,000 . Hal ini terjadi karena faktor BBLR saling berkaitan antara satu faktor dengan faktor lainnya. Pada usia kehamilan > 37 minggu dan bayi yang lahir dengan BBLR disebut sebagai dismaturitas yaitu neonatus cukup bulan kecil masa kehamilan.

e. Distribusi frekuensi berdasarkan anemia di RSUD Panembahan Senopati Bantul Yogyakarta Tahun 2017

\begin{tabular}{lccc}
\hline \multicolumn{1}{c}{ Anemia } & \multicolumn{2}{c}{ BBLR } & Nilai p \\
\cline { 2 - 3 } & F & \% & \\
Anemia $(\mathrm{Hb}<11 \mathrm{gr} / \mathrm{dl})$ & 5 & 2,9 \\
\hline Tidak Anemia $(\mathrm{Hb}>11 \mathrm{gr} / \mathrm{dl})$ & 169 & 97,1 & \\
\cline { 2 - 3 } & & 1,000
\end{tabular}


Total $174 \quad 100$

Berdasarkan tabel dapat dilihat bahwa ibu yang melahirkan BBLR lebih tinggi pada ibu yang tidak anemia sebanyak 169 orang $(97,1 \%)$ daripada ibu yang mengalami anemia sebanyak 5 orang (2,9\%). Diperoleh nilai $\mathrm{p}=1,000$ maka dapat disimpulkan tidak terdapat hubungan yang bermakna antara anemia dengan BBLR karena nilai $\mathrm{p}(1,000>0,05)$.

Anemia adalah kondisi dimana sel darah merah atau hemoglobin menurun sehingga kapasitas daya angkut oksigen dan nutrisi untuk keseluruhan organ-organ vital pada ibu dan janin menjadi berkurang (Varney, 2007). Pada ibu hamil dengan anemia terjadi gangguan penyaluran oksigen dan zat makanan dari ibu ke plasenta dan fungsi plasenta dapat menurun dan mengakibatkan gangguan tumbuh kembang janin (Cunningham, 2010).

Pada penelitian ini didapatkan hasil yang bertentangan yaitu ibu yang melahirkan bayi BBLR lebih banyak tidak anemia sebanyak 169 orang (97,1\%), karena cakupan pemberian tablet Fe di Kabupaten Bantul pada tahun 2017 sudah mencapai 95,45\% untuk tablet Fe1 dan 86,48\% untuk tablet Fe3 yang artinya hampir seluruh ibu hamil sudah meminum Fe sesuai anjuran pemerintah, adanya penanggulangan perbaikan gizi masyarakat termasuk anemia sehingga menjadi salah satu faktor ibu yang melahirkan BBLR banyak yang tidak anemia.

Penelitian tersebut sejalan dengan penelitian Handayani (2017) bahwa ibu yang melahirkan bayi BBLR lebih banyak pada ibu yang tidak anemia sebanyak 120 orang $(34,3 \%)$. Jika ibu hamil yang tidak anemia melahirkan bayi BBLR bisa disebabkan oleh faktor lain, seperti faktor pendidikan karena pendidikan mempengaruhi persepsi seseorang terhadap beberapa aktivitas dan sikap yang menyangkut kesehatan, seperti asupan makanan yang baik pada saat kehamilan dan melakukan pemeriksaan kehamilan ditempat kesehatan. Presepsi tersebut dipengaruhi oleh pengetahuan yang dimiliki setiap individu (Nurahmawati, 2017).

Hasil penelitian ini sejalan dengan penelitian Harti (2016) yang mengatakan bahwa ada hubungan antara status gizi dan pola makan 
terhadap penambahan berat badan dengan nilai $p$ value 0,008. Dari hasil penelitian ini menunjukkan bahwa sebagian besar responden berstatus gizi normal dengan rata-rata IMT $21,68 \mathrm{~kg} / \mathrm{m}^{2}( \pm 1,887 \mathrm{SD})$. Hasil penelitian tersebut didukung oleh penelitian Zulaikha (2015) yang mengatakan bahwa pola makan memiliki hubungan yang signifikan terhadap kejadian anemia pada ibu hamil trimester III. Hal ini menunjukkan bahwa pola makan yang baik akan menghasilkan asupan protein dan vitamin sesuai dengan kebutuhan tubuh dan proses metabolisme menjadi seimbang sehingga pembentukkan $\mathrm{Hb}$ dapat memenuhi kebutuhan tubuh. Hal itu lah yang menyebabkan banyaknya ibu memiliki status gizi yang baik dan tidak mengalami anemia.

f. Distribusi frekuensi berdasarkan preeklampsia di RSUD Panembahan Senopati Bantul Yogyakarta Tahun 2017

\begin{tabular}{lccc}
\hline \multicolumn{1}{c}{ Preeklampsia } & \multicolumn{2}{c}{ BBLR } & \multirow{2}{*}{ Nilai p } \\
\cline { 2 - 3 } & F & \% & \\
\hline $\begin{array}{l}\text { Preeklampsia } \\
\text { (terdapat protein didalam urine) }\end{array}$ & 21 & 12,1 & \multirow{2}{*}{0,000} \\
$\begin{array}{l}\text { Tidak Preeklampsia } \\
\text { (tidak terdapat protein didalam urine) }\end{array}$ & 153 & 87,9 & \\
Total & 174 & 100 & \\
\hline
\end{tabular}

Berdasarkan tabel dapat dilihat bahwa ibu yang melahirkan BBLR lebih tinggi pada ibu yang tidak mengalami preeklampsia yaitu sebanyak 153 orang $(87,9 \%)$ dan ibu yang mengalami preeklampsia sebanyak 21 orang $(12,1 \%)$. Diperoleh nilai $\mathrm{p}=0,000$ maka dapat disimpulkan terdapat hubungan yang bermakna antara preeklampsia dengan BBLR karena nilai $\mathrm{p}$ $(0,000<0,05)$. Dari nilai OR dapat dikatakan bahwa odds ratio pada ibu yang mengalami preeklampsia beresiko melahirkan BBLR 23,74 kali lebih besar dibandingkan dengan ibu yang tidak mengalami preeklampsia.

Preeklampsia terjadi karena vasokontriksi pembuluh darah dalam uterus yang menyebabkan peningkatan resistensi perifer sehingga terjadi peningkatan tekanan darah. Vasokontriksi pembuluh darah dalam uterus dapat mengakibatkan penurunan aliran darah sehingga suplai oksigen dan nutrisi ke janin berkurang. Ketika hal itu terjadi, dapat menyebabkan intrauterine growth retardation (IUGR) dan melahirkan bayi BBLR. Keadaan yang lain juga diperjelas akibat kegagalan arteri spiralis di 
miometrium untuk dapat mempertahankan struktur muskulus elastisitasnya, di samping itu juga terjadi arterosis akut pada arteri spiralis yang dapat menyebabkan lumen arteri bertambah kecil, keadaan ini akan menyebabkan infark plasenta dan bisa mengakibatkan hipoksia janin dan dapat mengakibatkan kematian janin. Preeklampsia meningkatkan resiko IUGR dan berat lahir rendah disebabkan penurunan aliran darah uteroplasenta, dan hal ini akan menyebabkan berat badan lahir rendah (Backes, 2011).

Pada penelitian ini dari total ibu yang mengalami preeklampsia sebanyak 22 orang dan yang melahirkan BBLR sebanyak 21 orang $(12,1 \%)$ yang artinya mayoritas ibu yang mengalami preeklampsia memiliki bayi BBLR. Hasil penelitian ini menunjukkan bahwa terdapat hubungan yang signifikan antara preeklampsia dengan kejadian BBLR. Penelitian tersebut sesuai dengan penelitian Theresia (2017) yang mengatakan bahwa adanya hubungan yang signifikan antara preeklampia dengan kejadian BBLR dengan nilai $p$ value 0,001 , dari penelitian tersebut diperoleh ibu yang mengalami preeklampsia dan melahirkan bayi BBLR sebesar 56,3\%. Hal tersebut karena preeklampsia merupakan salah satu faktor penyebab BBLR, karena pada preeklampsia terjadi plasentasi abnormal, iskemik plasenta kronis, spasme pembuluh dara, dan penurunan perfusi uteroplasenta, kemudian sirkulasi arah kejanin akan menurun sehingga janin mengalami kekurangan oksigen dan nutrisi. Penelitian tersebut disukung oleh penelitian Utami (2017) yang mengatakan bahwa preeklampsia merupakan faktor resiko lebih besar yang menyebabkan BBLR dengan $\mathrm{OR}=3,29$.

g. Distribusi frekuensi berdasarkan gemelli di RSUD Panembahan Senopati Bantul Yogyakarta Tahun 2017

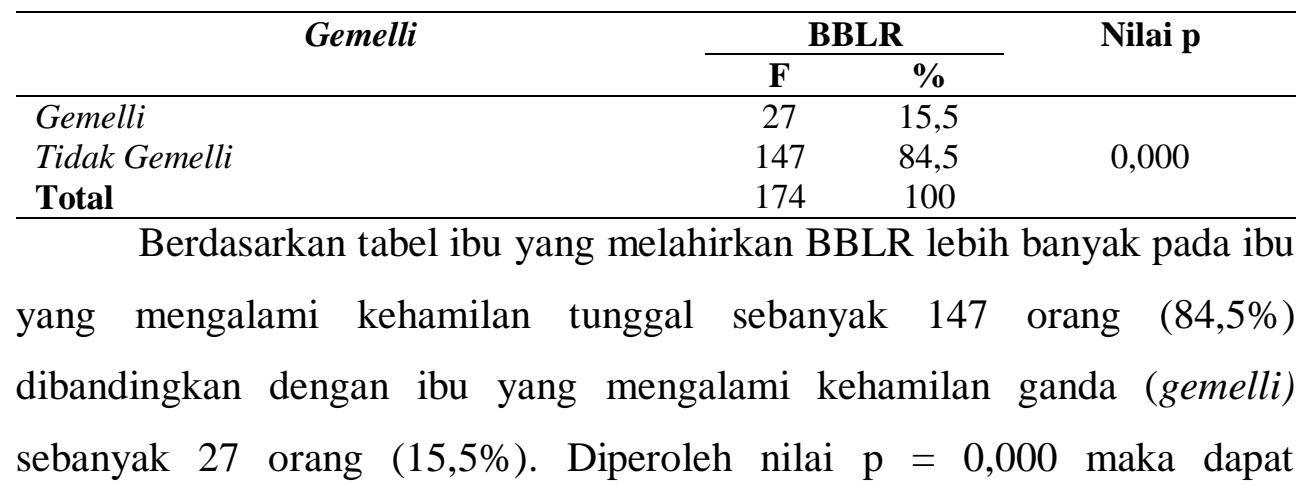


disimpulkan bahwa terdapat hubungan yang bermakna antara kehamilan ganda (gemelli) dengan BBLR karena nilai $\mathrm{p}(0,000<0,05)$. Dari nilai OR dapat dikatakan bahwa odds ratio pada kehamilan ganda (gemelli) beresiko melahirkan BBLR 10,46 kali lebih besar dibandingkan dengan ibu yang bukan kehamilan ganda (gemelli). Berat badan janin pada kehamilan kembar lebih ringan daripada janin pada kehamilan tunggal. Berat badan satu janin pada kehamilan kembar rata-rata 1000 gram lebih ringan daripada kehamilan tunggal. Sampai kehamilan 30 minggu kenaikan berat badan janin kembar sama dengan janin kehamilan tunggal (Prawirohardjo, 2010). Kehamilan ganda juga dapat menyebabkan komplikasi kehamilan pada trimester kedua dan ketiga yang berhubungan dengan janin seperti Intaruterine Growth retardation (IUGR), pertumbuhan prematuritas, terjadi anomali pertumbuhan, juga dapat membuat janin kecil sampai meninggal (Manuaba, 2010).

Pada penelitian ini dari total kehamilan ganda sebanyak 30 orang $(8,6 \%)$ dan yang melahirkan bayi BBLR yaitu sebanyak 27 orang $(15,5 \%)$ yang artinya mayoritas ibu yang memiliki kehamilan ganda mengalami BBLR. Hal ini sesuai dengan teori yang ada bahwa ibu yang memiliki kehamilan ganda cenderung melahirkan bayi BBLR. Penelitian ini juga didukung oleh penelitian (Jumhati \& Novianti, 2018) menyatakan bahwa adanya hubungan yang signifikan kehamilan kembar dengan kejadian BBLR. Ibu yang mengalami kehamilan kembar memiliki peluang 9 kali melahirkan bayi BBLR dibandingkan dengan ibu yang tidak hamil kembar.

Penelitian tersebut juga didukung oleh penelitian Oktaviani (2017) yang mengatakan bahwa kehamilan ganda (gemelli) memiliki hubungan yang signifikan dengan kejadian BBLR dengan nilai $p$ value 0,000. Pada penelitian ini diketahui bahwa sebagian besar responden yang melahirkan di RSUD Panembahan Senopati Bantul adalah tidak hamil ganda sebanyak 147 orang $(84,5 \%)$, hal ini disebabkan karena tidak semua responden yang diteliti memiliki faktor predisposisi hamil ganda. 


\section{Kesimpulan}

\section{Simpulan}

Variabel yang memiliki hubungan signifikan terhadap BBLR adalah paritas $(p=0,033)$, jarak kelahiran $(p=0,012)$, usia kehamilan $(p=0,000)$, preeklampsia $(\mathrm{p}=0,000)$ dan gemelli $(\mathrm{p}=, 000)$.

\section{Saran}

Dari hasil penelitian ini diharapkan bidan dapat bekerjasama dengan kader posyandu di setiap wilayah untuk memantau pemenuhan gizi ibu selama hamil, sehingga dapat melakukan deteksi dini bagi ibu yang memiliki resiko melahirkan BBLR.

\section{Daftar Pustaka}

Afroh, F., \& Sudarti. 2013. Asuhan Kebidanan Neonatus Risiko Tinggi dan Kegawatan. Yogyakarta: Nuha Medika.

Arikunto, S. 2010. Prosedur Penelitian Suatu Pendekatan Praktik. Jakarta: Rineka Cipta.

Backes, C.H., Markham, K., Moorehead, P., et al., 2011. Maternal preeclampsia and neonatal outcomes, Journal Pregnancy 2011: 214365.

Cuningham, FG., Macdonald, PC. \& Gant, NF. 2010. Obstetric Williams, PP. Jakarta : EGC.

Dinas Kesehatan Bantul. 2018. Profil Kesehatan Kabupaten Bantul Tahun 2017. Yogyakarta : Depkes DIY.

Dinas Kesehatan DIY. 2017. Profil Kesehatan Daerah Istimewa Yogyakarta Tahun 2017. Yogyakarta : Depkes DIY.

Ernawati, Wahyu. 2016. Hubungan Faktor Umur Ibu dan Paritas dengan kejadian Bayi Berat Lahir Rendah di Rumah Sakit Umum PKU Muhammadiyah Bantul Tahun 2016. Skripsi. Yogyakarta : Universitas 'Aisyiyah Yogyakarta.

Handayani, Fitri. 2017. Faktor-Faktor yang Berhubungan dengan BBLR di RSUD Wates Kulon Progo. Skripsi. Universitas'Aisyiyah Yogyakarta. 
Harti, LB., Kusumastuty, I., Hariadi, I. 2016. Hubungan Status Gizi dan Pola Makan terhadap Penambahan Berat Badan Ibu Hamil, Indonesia Journal of Human Nutrition, 54-62.

Holmes, D., \& Baker, P. 2011. Buku Ajar Ilmu Kebidanan. Jakarta: EGC.

Jumhati, S., \& Novianti, D. 2018. Analisis Faktor-Faktor yang Berhubungan dengan Kejadian BBLR di Rumah Sakit Permata Cibubur-Bekasi. Jurnal Ilmu Kesehatan Masyarakat, 113-119.

Kemenkes RI. 2013. Buku Saku Pelayanan Kesehatan Ibu di Fasilitas Kesehatan Dasar Dan Rujukan. Jakarta : Kementrian Kesehatan RI 2013.

Kemenkes RI. 2017. Profil Kesehatan Indonesia Tahun 2017. Jakarta: Kementrian Kesehatan RI 2018.

Kemenkes RI. 2018. Riskesdas 2018. Jakarta : Badan Penelitian dan Pengembangan Kesehatan Kemenkes RI.

Khotimah, K. 2017. FAktor-Faktor Yang Mempengaruhi Kejadian Bayi Baru Lahir Dengan Berat Badan Lahir Rendah Di RSUD Wonosari. Skripsi. Universitas 'Aisyiyah Yogyakarta.

Manuaba, I. B. 2010. Ilmu Kandungan dan KB. Jakarta: EGC.

Nuharmawati, Dhewi. 2017. Pengaruh Tingkat Pendidikan, Pendapatan Keluarga, Stres Psikososial, Status Gizi, Anemia Gravidarum Pada Ibu Hamil Terhadap Berat Badan Lahir Rendah Di Kabupaten Nganjuk. Tesis. Universitas Sebelas Maret.

Oktaviani, ET. 2017. Hubungan Usia, Paritas Dan Kehamilan Ganda Dengan Kejadian BBLR di RSUD Abdoel Moeloek Provinsi Lampung Pada TAhun 2016, Jurnal Kesehatan Akbid Wira Buana, 7-16.

Pamungkas, RS, Argadireja, DS \& Sakinah, RK. 2016. Hubungan Usia Ibu dan Paritas dengan Tingkat Kejadian BBLR di Wilayah Kerja Puskesmas Plered, Kecamatan Plered Kabupaten Purwakarta Tahun 2014. Prosiding Pendidikan Dokter, Universitas Islam Bandung.

Pinontoan, VM. \& Tombokan, SGJ. 2015. Hubungan Umur dan aritas Ibu dengan Kejadian Bayi Berat Lahir Rendah, Jurnal Ilmiah Bidan, 20-25..

Prawiroharjo. 2011. Ilmu Kebidanan. Jakarta: Bina Pustaka.

Proverawati, A., \& Ismawati, C. 2010. Berat Badan Lahir Rendah (BBLR). Yogyakarta: Nuha Medika. 
Setiati, AR \& Rahayu, S. 2017. Faktor Yang Mempengaruhi Kejadian BBLR (Berat Badan Lahir Rendah) Di Ruang Perawatan Intensif Neonatus RSUD Dr Moewardi Di Surakarta. Jurnal Keperawatan Global, 1-61.

Sharesta, Ruma. 2016. Obstetric Risk Factors For Low Birth Weight Amongst Full Term Babies Born at A tertiary Care Hospital. National Journal of Community Medicine. Vol 5 Issue 3.

Theresia, Yohani. 2017. Hubungan Antara Preeklampsia Dengan Luaran Berat Badan Bayi Di RSUP H. Adam Malik Medan. Skripsi. Universitas Sumatera Utara.

Umboh, A. 2013. Berat Lahir Rendah dan Tekanan Darah Pada Anak. Jakarta: Sagung Seto.

Utami, U. 2017. Hubungan Antara Preeklampsia Berat Dengan Kejadian Berat Lahir Rendah (BBLR) Di RS. Oen Surakarta. Skripsi. UMS.

Varney, H, Kriebs, Jan M, Gregor, Carolyn. 2007. Buku Ajar Asuhan Kebidanan. Vol 1. Jakarta : EGC.

Zulaikha, Eva. 2015. Hubungan Pola Makan Dengan Kejadian Anemia Pada Ibu Hamil Trimester III Di Puskesmas Pleret Bantul. Skripsi. Universitas 'Aisyiyah Yogyakarta. 